\title{
Tailoring Faculty Development Programs to Faculty Career Stages
}

\author{
Peter Seldin \\ Pace University
}

College faculty progress through a series of sequential career stages. Each is characterized by different motivations and professional development needs. Yet, too often, faculty developers rely on hunches rather than empirical data to guide programming decisions. This chapter describes the important research findings of a just completed national study to determine the different programming interests and needs of more than 500 beginning, mid-career, and senior-level faculty in the United States.

\section{Introduction}

At the 2003 POD (Professional and Organizational Development Network in Higher Education) Conference, six friends-all long-term members of POD-had dinner together. During the course of the evening, our wideranging conversation eventually narrowed, and we began to focus on our own aging. We discussed our changing professional needs and personal interests and agreed that they were quite different now from what they were years earlier. We felt certain that the evolution in our needs and interests were likely similar to changing needs and interests of faculty at our institutions as they experienced their own aging.

After the POD conference ended, I returned to my own university and read some of the literature on the topic of faculty career stages. Particularly helpful was the work of Austin (2002); Baldwin (1985); Bland and Bergquist (1997); DeZure (2002); Kalivoda, Sorrell, and Simpson (1994); Karpiak (2001); Rice, Sorcinelli, and Austin (2000); Robertson (1999); Robertson 
(2000); and Sandberg (2003). All wrote that faculty careers evolve over time as professors mature, gain experience, and revise their interests and professional objectives. They said that professors progress through a series of sequential career stages and that each is characterized by different demands, different motivations, and different professional development needs.

That conclusion seemed logical and reasonable to me. After all, the findings were consistent with widely accepted theories of human development, aging, and developmental psychology. But I wanted to go beyond the theories and directly ask faculty at different career stages about their specific developmental needs. My goal was to match career stages to specific professional development needs.

\section{The Study}

Three broad career stages were used: beginning faculty (1-5 years in the classroom), mid-career faculty (10-20 years in the classroom), and senior faculty ( 30 or more years in the classroom). A one-page questionnaire listing an array of possible professional development activities was developed and field tested at my own university. It asked participants to indicate the number of years they had been teaching, and identify the development activities on the list in the questionnaire that were most relevant to them at this point in their careers.

After a small number of adjustments for clarity, in spring 2004 the revised questionnaire (see Appendix 10.1) was distributed to the academic deans of 30 colleges and universities across a range of Carnegie classifications. Also included was a cover letter that explained the purpose of the study and asked for the deans' help in forwarding the questionnaire to a sampling of beginning, mid-career, and senior faculty at their institutions. A total of 618 questionnaires were distributed, and 508 were returned to the author with usable data. The overall response rate of $82 \%$ was virtually the same across the three faculty career stages. It is an unusually high rate of return for social science research, but it is consistent with the rate of return I have obtained in 10 previous national studies.

\section{Results}

: Beginning College Faculty (1-5 Years in the Classroom)

Beginning teachers are at a transition point in their careers. They have left the friendly comfort zone of graduate school where they knew the major players, 
the daily routine, what to do, and what not to do. Now they have begun their professional careers in a new and unfamiliar environment and many are learning to perform their duties in the classroom by trial and error. To their dismay, beginning faculty have learned that earning their doctorate does not mean that they have complete knowledge of their discipline and that they may well be assigned to teach courses that are outside their narrow field of specialization. At the same time, many are struggling to find an appropriate balance between teaching and scholarship and between their personal and professional lives.

This is the context within which beginning professors work. The development activities they selected in the survey as most relevant to them follow. The headings in italics that precede the developmental activities are my suggestions of umbrella topics under which the activities can be grouped.

Opportunities to acquire new knowledge in their academic field of specialization. Beginning faculty may be newly minted doctorates but they still have a strong need to expand their knowledge base in their chosen discipline. Participants in the study said that this need can be meet effectively if an institution:

- Provides modest financial grant support to enable them to initiate new discipline-specific scholarly research

- Provides resource help-financial and otherwise-to attend disciplinespecific programs and conferences

- Provides support for the purchase of discipline-specific readings, reports, CDs, and periodicals

- Offers faculty development programs that address the value and usefulness of collaborative discipline-specific scholarly work

Programs to develop their skill in the classroom. Unless beginning faculty members took part in a strong TA training program on teaching during graduate school, they have an urgent need to enhance their skill in the classroom. This can be met through well-designed, campus workshops on such topics as:

- Teaching techniques

- Testing student knowledge

- Use of educational technology

- Course design

- Leading classroom discussions or lecturing 
Programs on time management and balance between professional and personal lives. Beginning faculty are typically swamped by an array of time-consuming tasks. They need to learn how to manage their limited time and how to create balance in their lives. These needs can be met by well-developed workshops as well as occasional programs to orient them to their new professional home.

\section{- Mid-Career College Faculty (10-20 Years in the Classroom)}

In most cases, mid-career faculty are recognized as reasonably competent in their disciplines and in the classroom. But they are confronted with a dilem$\mathrm{ma}$ in their careers: As they anticipate another 25-30 years in the academic profession, do they maintain the same career path they have traveled to this point? Or do they take on new professional activities and new roles? For many, mid-career is a turning point in their academic lifecycle.

This is the context within which mid-career faculty work. The development activities that they selected in the survey as most relevant to them follow. The heading in italics reflects my suggestion of an umbrella topic for the chosen activities.

Opportunities to redefine and enlarge the scope of their professional careers. Participants in the study said that this important need can be met if an institution provides such professional development opportunities as:

- A weekend career assessment and planning workshop to help them focus systematically on the future. The workshop encourages faculty to explore new areas and new avenues for broadening their perspectives, deepening them, and maybe even changing them.

- Rotation of administrative positions or other short-term non-teaching assignments. A year or two as an assistant dean or director of institutional assessment gives a mid-career faculty member a break from the routine of teaching and, at the same time, enables the institution to take advantage of the faculty member's talents. Similarly, chairing a major institutional task force at one's institution provides healthy variety in an academic career.

- Faculty exchanges, such as a year as a visiting professor at another institution, provide an opportunity for faculty to engage with new colleagues and experience new perspectives on teaching strategies, disciplinary issues, and maybe even institutional policies. 
- Summer internships in a corporation or government agency offer opportunities for mid-career faculty members to learn new skills and acquire new knowledge in their academic disciplines.

- Opportunities to lead a group of students on a trip abroad for a two- or three-week academic experience. Leading such trips permits faculty to interact with their students in a refreshingly new way in a different venue and further develops faculty organizational and leadership skills.

\section{Senior Faculty (30 or More Years in the Classroom)}

Senior faculty are the elder statespersons at their institutions. Most are between the ages of 55 and 65 and have worked at their institutions for many years. They have risen through the academic ranks to a senior position and many have held short-term administrative positions within their college or university, such as assistant dean, special assistant to the provost, or chair of an institutional self-study committee.

But at this point in their careers, they may find their influence diminishing as many of their long-term colleagues retire and as younger colleagues assume the important departmental roles that they held previously. At the same time, senior faculty may experience a disturbing sense of disquiet as the age gap between themselves and their students widens and they realize that some of their students are young enough to be their grandchildren.

This is the context in which senior faculty work. The development activities they selected as most relevant to them follow. The headings in italics reflect my suggestion of umbrella topics for the chosen activities.

The need to leave behind a meaningful and lasting legacy. This is consistent with the idea that a principle task of adult life is the quest for a sense of generativity - a need to produce something that will outlive oneself, to leave a legacy in some way. Participants in the study said that this need can be effectively met if an institution:

- Provides an opportunity for senior faculty to mentor young colleagues, either junior faculty or graduate students. Those with decades of experience in the higher education trenches can serve as master teacher, research design specialist, or career counselor to their younger colleagues. They can assist them in knowing the vital ropes to climb and the less important ropes to skip.

- Offers a convenient way for senior faculty to give something back to the community, both within and outside the institution. Senior faculty can volunteer time and expertise to assist their institution with a major 
project-for example, serving on a fundraising or athletic department task force or directing new faculty orientation. They can also contribute time and expertise to the outside community-for example, serving on a town beautification committee or a task force to enhance the quality of education in the local high school.

Preparation for retirement. Senior faculty who are about to retire are entering unchartered waters. They have no experiential background to fall back on. Too often, institutions fail to recognize the crucial need of senior faculty for information and guidance as they approach the tail end of their academic careers and prepare for retirement. This important need can be met if an institution:

- Provides an opportunity for senior faculty to get together for dialogue about the financial aspects of retirement. Institutions can offer programs presented by TIAA-CREF that address this vital aspect of retirement. The focus would be on examining one's financial assets, typical monthly expenses, and expected monthly payout from TIAA-CREF.

- Provides an opportunity for senior faculty to address the important $p s y$ chological aspects of retirement. Consider the new life of just-retired senior faculty members: No longer do they prepare for classes. No longer do they have faculty colleagues to talk with. No longer do they have a place to go each morning. The loss of these things has a powerful impact on a person's sense of self. That's why veteran faculty can benefit from programs that provide psychological support as well as those that offer financial support.

- Facilitates structured meetings between those who will retire shortly and those who have already retired, especially those who retired within the last few years. The goal is for those who are about to retire to learn from academic colleagues who have already done so such things as what to expect, how to productively use their time, things to do, pitfalls to avoid, important things they wish they had known before they retired.

\section{Additional Finding}

The study also found that faculty at all career points can benefit from certain opportunities to enhance their professional performance. Participants at all three career stages-beginning, mid-career, and senior level-said they could benefit from developing and annually updating a teaching portfolio and attending brown-bag lunches with faculty colleagues to share research, 
common readings, or teaching strategies. This result will not be surprising to faculty developers who have noted that faculty at all three career stages typically take part in programs focused on preparing and updating teaching portfolios as well as brown-bag lunches that are structured to encourage informal faculty discussion at their colleges or universities.

\section{Implications for Faculty Developers}

In this era of scarce resources, few institutions can afford to offer a large number of programs that are geared only to faculty at a particular career stage. It is just too costly. But too often institutions offer no such programs. The rationalization is that many faculty will get something out of broad-based programs, even if they are not geared to the needs of their individual career stages. There is probably some truth to that perspective, but I would argue that faculty development programs would better serve their constituents by finding a middle ground and offering at least some programs geared to faculty at specific career stages. How might this be done?

At a minimum, institutions could offer an occasional program or twoon a rotating semester or annual basis-geared to faculty at a specific career stage. For example, a program of special interest to beginning faculty could be offered one year, the next year, a program of special interest to mid-career faculty, and the following year, a program geared to senior faculty.

This would be an important first step in recognizing that while faculty at all career stages can benefit from certain opportunities, other programs and activities are better suited to the professional development needs of faculty at specific career stages.

\section{References}

Austin, A. E. (2002). Preparing the next generation of faculty: Graduate school as socialization to the academic career. Journal of Higher Education, 73(1), 94-122.

Baldwin, R. G. (Ed.). (1985). New directions for higher education: No. 51. Incentives for faculty vitality. San Francisco, CA: Jossey-Bass.

Bland, C. J., \& Bergquist, W. H. (1997). The vitality of senior faculty members: Snow on the roof-fire in the furnace (ASHE-ERIC Higher Education Report, 25[7]), Washington, DC: George Washington University. 
DeZure, D. (2002). Priorities/concerns of faculty at several career stages. Paper presented at a University of Michigan Faculty Seminar, Ann Arbor, MI.

Kalivoda, P., Sorrell, G. R., \& Simpson, R. D. (1994). Nurturing faculty vitality by matching institutional interventions with career-stage needs. Innovative Higher Education, 18(4), 255-272.

Karpiak, I. E. (2001). Midlife: The "second call" for faculty renewal. The Department Chair, 11(4), 11-12.

Rice, R. E., Sorcinelli, M. D., \& Austin, A. E. (2000). Heeding new voices: Academic careers for a new generation (New Pathways Working Paper Series No. 7). Washington, DC: American Association for Higher Education.

Robertson, D. L. (1999). Professors' perspectives on their teaching: A new construct and developmental model. Innovative Higher Education, 23(4), 271-294.

Robertson, D. R. (2000). Professors in space and time: Four utilities of a new metaphor and developmental model for professors-as-teachers. Journal on Excellence in College Teaching, 11(1), 117-132.

Sandberg, K. (2003). Senior professors, too, sometimes need a helping hand. The Department Chair, 14(1), 26-27. 


\section{Appendix 10.1 \\ Faculty Survey}

What is your teaching career stage? (If you are between stages, check the stage that you are closest to at the end of this academic year.)

Beginning faculty ( $1-5$ years)

Mid-career faculty (10-20 years)

Senior faculty ( 30 or more years)

Instructions: Please rate the level of relevance that you assign to each of the following professional development activities. Place a checkmark at the appropriate response level for each item.

\begin{tabular}{l} 
Development Activities \\
\hline $\begin{array}{l}\text { Attending a workshop on time management } \\
\text { Holding a rotating administrative position }\end{array}$
\end{tabular}




\begin{tabular}{llll}
\hline Development Activities & Most relevant \\
\hline Taking part in a summer internship & Least relevant \\
Leading a group of college students on \\
a trip abroad
\end{tabular}

